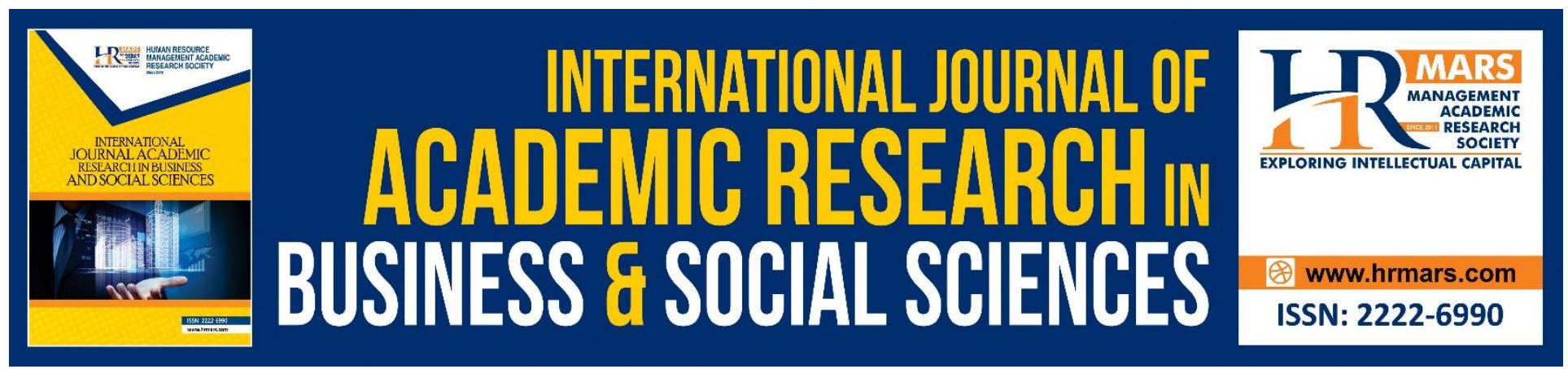

\title{
Malaysian Land Tribunal: Necessity or Sheer Hospitality
}

Mimi Sofiah Ahmad Mustafa, Yuhanza Othman, Marziana Abd Malib, Ida Rahayu Mahat

To Link this Article: http://dx.doi.org/10.6007/IJARBSS/v10-i7/7605

DOI:10.6007/IJARBSS/v10-i7/7605

Received: 24 May 2020, Revised: 17 June 2020, Accepted: 12 July 2020

Published Online: 29 July 2020

In-Text Citation: (Mustafa et al., 2020)

To Cite this Article: Mustafa, M. S. A., Othman, Y., Malib, M. A., \& Mahat, I. R. (2020). Malaysian Land Tribunal: Necessity or Sheer Hospitality. International Journal of Academic Research in Business and Social Sciences, 10(7), 761-775.

Copyright: (C) 2020 The Author(s)

Published by Human Resource Management Academic Research Society (www.hrmars.com)

This article is published under the Creative Commons Attribution (CC BY 4.0) license. Anyone may reproduce, distribute, translate and create derivative works of this article (for both commercial and non-commercial purposes), subject to full attribution to the original publication and authors. The full terms of this license may be seen at: http://creativecommons.org/licences/by/4.0/legalcode

Vol. 10, No. 7, 2020, Pg. 761 - 775

http://hrmars.com/index.php/pages/detail/IJARBSS

JOURNAL HOMEPAGE

Full Terms \& Conditions of access and use can be found at http://hrmars.com/index.php/pages/detail/publication-ethics 


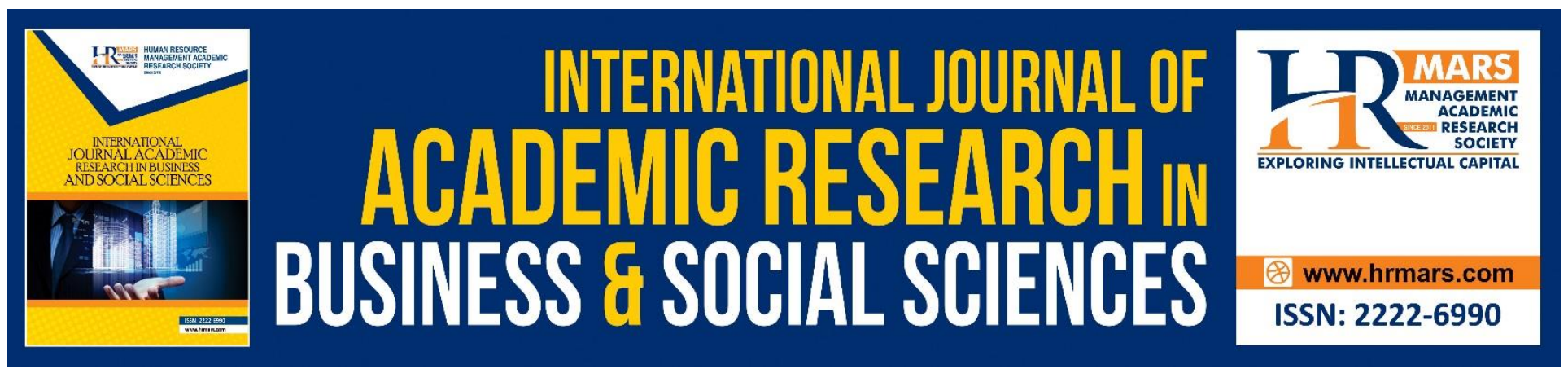

\title{
Malaysian Land Tribunal: Necessity or Sheer Hospitality
}

\author{
Mimi Sofiah Ahmad Mustafa, Yuhanza Othman, Marziana Abd \\ Malib, Ida Rahayu Mahat
}

Law Department, Universiti Teknologi MARA Melaka Branch, Malaysia

\begin{abstract}
Tribunal plays as an alternative channel for the public to bring a claim against another party due to its informality, low in cost and speedy process. Since 1999, the Malaysian government has formed several tribunals including the Tribunal for Consumer Claim (TCC) to hear and determine all consumer claims relating to consumerism under the Consumer Protection Act 1999 (CPA). Then in 2002, the government established a Tribunal for Homebuyer Claims under the Housing Development (Control \& Licensing) Act 1966 to deal with all disputes involving house buyers and housing developers. Despite of wide jurisdictions governing both tribunals, there is still lacking in jurisdiction with regards to land issues such as disposal of land, lease of land, rent, recovery of land, interest in land and trespassing on land. Due to that, the claimant needs to bring the case to civil courts which are costly with strict procedures to comply to. This paper analyzed the existing law regarding land dealings and studied the possibility of having a new tribunal which specifically hears cases involving land dealings. It also looked at the possibility of having the concept of sulh in the tribunal proceeding. This doctrinal research, using a qualitative method, had most of its data collected through library research and internet resources. Other than that, to achieve the objectives of this research, several experienced lawyers, people linked to tribunals such as those working at TCC and bank legal advisors and experts from the Islamic Department were also interviewed. All respondents interviewed and the library research showed that there is a necessity to establish a body outside the court system to handle land cases so as to reach speedier decisions.
\end{abstract}

Keywords: Land Issues, Sulh, Tribunal, Law Amendment, Speedier Decision.

\section{Introduction}

Every dispute needs a solution. In terms of the quality of settlement, a settlement based on any provision of the law is preferred because it is achieved in accordance with the state law. This means that each party are bound by the decision of the decision-making authority and they are also allowed to appeal if they are not satisfied with the decision reached.

The Tribunal is one of the alternatives that the public can refer to in order to resolve certain disputes based on existing laws and such issues can be related to rent matters, consumption of goods, employment, taxation issues and so on. It is an alternative to the court and its decision is binding on 
the parties involved. Jain (2012) shared that the tribunal differs from the court in terms of its atmosphere because it is less formal; in terms of the cost, it is cheaper; in terms of the results, it is faster; in terms of the decision-making panels, it contains panelists who specialize in disputes and most importantly, this tribunal is neutral in that it is not related to any party such as the government departments or any individuals or private companies. Fabri (2019) further stated that the tribunal practices openness in its trial which is the key to a fair trial and thus a principal requirement to the rule of law.

Any dispute over land in Malaysia today can only be resolved in the courts of the Malaysian judicial system according to section 23 Courts of Judicature Act 1964 . This is because there is no provision in any law that gives jurisdiction to any institution other than the court to settle cases involving land and its interests. Among the cases involving land are the issue of inheritance, ownership and ownership of land, compulsory acquisition of land, interest in land such as rent and land revenue, encroachment on land such as squatting, misappropriation of land interest, abuse of power by trustee over land and so on.

A case with land issues that is tried in courts does not take a short time to decide. It has to go through certain court procedures that are not easy to understand. The relatively formal court atmosphere also probably leads the parties involved to feel uncomfortable to testify, especially when it involves personal information that needs to be clarified in the court. The cost of hiring a lawyer to bring a case to court is also higher than the case brought to the tribunal because the plaintiff may not have the necessary legal knowledge to handle the case but the plaintiffs can represent themselves in disputes brought to the tribunal. As noted above, the composition of a tribunal are experts in the field concerned of any case. For example, if the issue is on housing, the panelists for the tribunal will consist of experts such as architects, quantity surveyors and engineers.

Dato' lan Chin (2019), a retired judge who had enormous experience in delivering judgment both in civil and criminal cases, shared some horrifying facts relating to case management in courts where there were bundles of cases that could not be settled early just because the dates for trials could not be ascertained in a short period of time. For example, he specifically mentioned in a claim for land compensation where the case was entered to the court for trial on 16/03/2004 but the date for trial was only fixed 06/03/2007 and the trial took place on 04/11/2008. Another example which involved a charge of possession of land which came to court on 17/03/2004 but was only on trial on $18 / 11 / 08$ after being fixed for trial on 20/03/07. The judge further declared that there were cases that did not even need to have trials but had to endure a long period of time to be settled.

This paper explored the possibility of a special tribunal to resolve the land issue in Malaysia or at least it could be placed under the jurisdiction of the existing Housing Tribunal in the country. Plus, this article also looked at the extent to which it was possible to amend the provisions of the Consumer Protection Act 1999 (Section 2) to explicitly include the jurisdiction of the Tribunal for Consumer Claim (TCC) to handle land-related cases.

In addition, this paper investigated the likelihood of adopting the sulh concept in Islamic law in a land tribunal for a better solution in land issues. Fazaluddin (2016) in his writings on the ethics of peace in the Quran defines sulh as peace. It can be regarded as a way to resolve dispute instead of bringing the issue or case to the courts of law. The authors found this is an interesting and amicable peace settlement that probably does not involve any hardship on both parties to the dispute with regards to land. 
INTERNATIONAL JOURNAL OF ACADEMIC RESEARCH IN BUSINESS AND SOCIAL SCIENCES

Vol. 10, No. 7, July, 2020, E-ISSN: 2222-6990 @ 2020 HRMARS

The authors feel that the establishment of the Land Tribunal is necessary because there are many cases involving small land issues that should be resolved quickly on other platforms besides the civil courts in the existing judicial system in Malaysia. Cases such as arrears of rent or cases of unreasonable land rent should not be brought to the ordinary civil court for settlement. These issues are easier to be resolved in a land court that is more informal and easier to determine than having them heard and decided in the long winded costly court system.

\section{Materials and Methods}

This study adopts qualitative research method using a doctrinal research approach which involved collection of secondary data in the form of description from online published journals, online reported law cases and books. The statutes and provisions in various laws relating to land matters, tribunal, mediation and sulh were also analysed. Apart from that, the data collection also involved unstructured interview with lawyers, bankers, land officers and officers from the Ministry of Domestic Trade, Cooperatives and Consumerism Ministry (KPDNKK). The interviews were conducted over the telephone and internet messages such as WhatsApp's and personal messages. The questions of interviews involved the experiences and problems faced by lawyers in handling land cases in courts, and the opinions of all the interviewees regarding any alternative methods to curb the problems.

\section{The existing land laws in Malaysia Syariah Law}

The Syariah law has been largely applied during Malacca Sultanate where Hukum Kanun Melaka (Malacca Legal Code) and Undang-Undang Laut Melaka were codified during that time. The administration of land, particularly was, according to Islamic law where it introduced that all lands belong to the Sultan but people were allowed to occupy and cultivate the land (Wu \& Zul Kepli, 2011). This could be seen in the case of Sharip v Mitchell (1870) Leic 446.

"It is well known that by the old Malay law or custom of Malacca, while the sovereign was the owner of the soil, every man had nevertheless the right to clear and occupy all forest and wasted land, subject to the payment, to the sovereign, of one tenth of the produce of the land so taken... If he abandoned the paddy land or fruit trees for more than three years, his right ceased and the land reverted to the sovereign".

\section{The Torrent System}

The experience of being administered exclusively by Syariah law had been interrupted when British intervened Malaya in 1924. The administration of civil law and criminal law were absolutely influenced by British administration system. They succeeded in separating Syariah law from the administration of justice and made it only relevant to Muslim affairs such as inheritance, marriage and divorce. In early 1920s, the British introduced a new law relating to land where the Torrent system was slowly adopted. According to the Torrent system, all land dealing and acquisition and interest relating to land must be registered which was supposedly supplied security for people dealing with land matters. The Torrent system emphasized on the registration of title into the land office in order to get indefeasibility of title (Zaki et.al., 2010). 
INTERNATIONAL JOURNAL OF ACADEMIC RESEARCH IN BUSINESS AND SOCIAL SCIENCES

Vol. 10, No. 7, July, 2020, E-ISSN: 2222-6990 @ 2020 HRMARS

\section{The National Land Code (NLC)}

After independence, the Torrent system was replaced by the new land code and all law administered in the Torrent system were embodied in the National Land Code (NLC). This NLC was coming into effect on the 1 January 1966. According to the Parliament Hansard dated 16 August 1965, the objectives of the NLC were to establish a uniform and clear system of land tenure and land dealing. The introduction of the NLC would combine, compile and incorporate all existing land law and system during that time. NLC could be regarded as the comprehensive land law which covers land registration system, disposal of land, jurisdiction of state and federal on land, alienation of land and others. Despite of that, it has gone through several amendments and the latest amendment was in the year of 2016.

\section{The Federal Constitution}

In Malaysia, all governing laws must conform and be in-line with the Federal Constitution (FC). According to article 4 of the FC, the FC is regarded as the supreme law in Malaysia and any law which contradicts with the FC shall be null and void. Despite the significance of the NLC, it shall be made in uniformity with the FC. According to List II of the article 74, land is under jurisdiction of the state. The ruler of each state has the power to make rules, regulations, enactment and any codified law regarding any matter listed in the State List where land is one of the matters listed therein. However, based on Article 76 of the FC, the Malaysian parliament may make law pertaining to any matter listed in the State List for the purpose of promoting uniformity of law and if requested by the State Legislative Assembly. Therefore, although FC promulgated that land is under the state legislative power, it still upholds the power of the parliament to override the State List in the event to seek uniformity between all the fourteen states within Malaysia.

\section{The Housing Developers Act 1966}

The development in the housing accommodation project from year to year initiated the parliament to enact the Housing Developers Act 1966 (HDA) which came into effect on 29 August 1969. This Act was introduced mainly to provide protection for house buyers and emphasized the responsibilities of housing developers in the housing development project they had started. The HDA also has similar experience as the NLC where it had gone through several amendments from the year of its introduction to the latest amendment in 2006. The specialty of the HDA as compared to the NLC is that, the HDA does expressly stipulate the duty of the Minister to establish the Tribunal for Home Buyers Claims (THBC).

\section{The Strata Title Act 1985}

According to the NLC, the subsidiary title means the title that is issued to any individual parcels within a building which has been subdivided. The subdivided land relates to a house which governed under the Strata Title Act 1985. The Act was enacted in 1985 and due to many unsettled issues arising from its inadequacy prior to the Strata Act had led the government to amend this Act several times and the latest amendment was gazetted in 2016. It is hoped that the new Act could curb the lacuna of the prior law. 
INTERNATIONAL JOURNAL OF ACADEMIC RESEARCH IN BUSINESS AND SOCIAL SCIENCES Vol. 10, No. 7, July, 2020, E-ISSN: 2222-6990 @ 2020 HRMARS

\section{The Existing Alternative Dispute Resolution (ADR) in Malaysia}

Alternative Dispute Resolution (ADR) is a method of dispute resolution using methods other than claims in the Court (http://pengacaramuslim.com/alternative-dispute-resolution/L. This method is popular because it costs less than the cost of filing a case in a civil court. Technically, the ADR refers to the goal of resolving disputes other than through the courts or in other words, settlement of disputes achieved through alternative means of mediation.

The ADR process will begin with negotiations, which is a long process of negotiating matters that can be agreed upon and not agreed between the parties involved. Examples: face-to-face, by phone, correspondence, email and so on. Subsequently, mediation services called mediators will be used for processes involving third parties invited by disputing parties without the presence of third parties. Then, the Arbitration process will take place where the process is to identify and provide the best solution.

In the secondary stage, a Private Judge will be personally selected by the disputing parties if it is necessary to appoint experts in the matter being disputed such as issues on other than construction of terms and those subject to any law that which allow the judge to give opinions or opinion on his expertise. This is how the ADR process looks; it is more practical and economical than the litigation process in the courts of law in the normal judicial system.

The body responsible for drafting and introducing the arbitration method is known as the Malaysia Arbitral Tribunal Establishment (MATE). MATE is an establishment founded in the 1980s on the merits and mandates of professional and trade organisations as a Managerial Authority known as "Constituent Organizations" that formulates policies and rules regarding arbitrations and supported by non-governmental organizations (NGOs) as members of its allies. The establishment has been registered under the Trademark Act as a special brand and is protected as an intellectual property. MATE is also recognised and has legal personality and can sue and be indicted on his own behalf. MATE's operation and the power bestowed upon them are binding.

The recently updated MATE Rules 2006 Edition is in line with the recent development of the Arbitration Act 2005. These MATE Rules or Regulations apply to all domestic cases handled by MATE as an Arbitral Institution in which the parties are authorised by law to choose a procedure or appropriate method of handling disputes as done by MATE other than provided by the existing law (Arbitral-MATE.org).

As an example of a case in the international arena, Malaysia and Singapore have different views on the fees to be paid for three areas of land in Tanjong Pagar, Kranji and Woodlands. Accordingly, the two leaders of the two countries agreed to bring the issue in connection with the pending payment of land development for the railway of Keretapi Tanah Melayu Berhad (KTMB) in the Republic to the International Arbitration Court (Mathew, 2018). Clearly, this method remains a good alternative at international level as opposed to the concept of litigation in the courts of law.

In the case of AV Asia Sdn Bhd v MEASAT Broadcast Network Systems Sdn Bhd [2014] 3 MLJ 61, AV Asia filed a suit against MEASAT for allegedly breaching an agreement between them. However, the High Court ruled that the matter should have been resolved by the ADR method. This is because the misunderstanding involves a 'non-disclosure agreement,' which is about rain interference with systems designed to reduce satellite transmission interference. YA Azahar Mohamed ruled that although there was no arbitration agreement between AV Asia and Telesystem Electronic, it did not mean that the case against MEASAT could not be brought to arbitration. According to the judge, because the parties to the dispute had agreed to the 'non-disclosure 
INTERNATIONAL JOURNAL OF ACADEMIC RESEARCH IN BUSINESS AND SOCIAL SCIENCES

Vol. 10, No. 7, July, 2020, E-ISSN: 2222-6990 @ 2020 HRMARS

agreement' then the matter must be considered to be resolved according to ADR. Evidently, the ADR method is highly regarded as an alternative method other than the court process especially in matters that probably are confidential to be disclosed to the public as in the abovementioned case.

\section{Tribunal for Consumer Claim}

Before the establishment of the Tribunal for Consumer Claim, all claims against dishonest sellers and manufacturers could only be brought to the court. This caused hardship and difficulties to the buyers because they needed to incur a lot of expenses to pay lawyers to get represented and to pay court fees. Thus, to reduce the burden on the buyer, the government enacted the Consumer Protection Act 1999 and through the Act, the Tribunal for Consumer Claim (TCC) was established. The main function of TCC is to provide an alternative for the consumers to bring an action against dishonest sellers. TCC has the jurisdiction to hear the claims to the amount of up to RM25,000 and recently, the Domestic Trade and Consumer Affairs (DTCA) proposed the amendment to the amount of claim up to RM50,000 (The Malaysian Reserve, 9 July, 2019). Although TCC has wide jurisdiction to hear disputes relating to consumer affairs but it still does not extend its jurisdiction on land disputes.

\section{Tribunal for Home Buyers Claims (THBC)}

The government formed the THBC in 01 December 2002 pursuant to Section 16B of the Housing Development (Control and Licensing) Act 1966 (HDA). The jurisdiction of the THBC is limited to a claim brought by a homebuyer who had entered into a sale and purchase agreement with a developer Section 16(2) of HDA 1966. This means the Act only focuses on a cause of action pertaining to a house constructed by a developer such as on the issues of late delivery of vacant possession and the house which was built not in accordance with the sale and purchase agreement. The THBC does not have jurisdiction to hear any cases involving land recovery, estate and interest in land.

\section{Sulh under Syariah Enactment}

Sulh is referring to an agreement to resolve disputes between two parties. It is also known as mediation. Islamic law emphasises on the settlement of disputes in harmony without any chaos. Nora Abd Hak et al (2011) reported that, in the1990s, there was an increase of backlog of Syariah court cases in Malaysia and this caused dissatisfaction amongst the public towards Syariah court system. Apparently this was due to the insufficiency of manpower. Hence, sulh was introduced to resolve the glitch.

There are several proofs that explained the necessity of having sulh in dispute resolution. For example, Majallah al-Ahkam al-Adliyyah that had the influence of fiqh Hanafi was made a legal text and enacted by the Ottomans government in Turkey that provided for their provisions of șulh (alRamahi , 2008). The definition of șulh is mentioned in Article 1531 of the Majallah al-Ahkam alAdliyyah as a final resolution of disputes made in a voluntary manner or mutual agreement (Akhir, 1990). Based on this definition șulh is an agreement between two parties to the dispute for the purpose of reaching an agreement on any matter terms that are mutually agreed upon (Azimin \& Hidayat, 2019). The accomplishment of this agreement is necessarily binding on the parties and they must obey it because it is in accordance with Islamic law and the state law.

The role of sulh as an alternative dispute resolution has become one of the most widely discussed topics among the authors and comparisons are often made with mediation which is widely used in other countries. The Alternative Dispute Resolution (ADR) is an essential alternative dispute 
INTERNATIONAL JOURNAL OF ACADEMIC RESEARCH IN BUSINESS AND SOCIAL SCIENCES Vol. 10, No. 7, July, 2020, E-ISSN: 2222-6990 @ 2020 HRMARS

resolution in today's civil justice system. The Syariah Courts in Malaysia have applied the ADR concept to the family court settlement of court cases through the process of reconciliation, arbitration and needless to say, it is also the judiciary's own initiative (Aida, 2001).

Currently, as mentioned above, sulh is widely applied in the Syariah Court to settle disputes between married couples to avoid divorces. This is in-line with one of the verses in Surah an-Nisa, where Allah says that- anNisa (4:128);

"So it is not wrong for them (the husband or the wife) to make peace between the two (for the better), because it is better (for them) than divorce".

The Prophet Muhammad also said that, (hadith narrated by At-Tirmizi)

"Șulh is something that must be in existence in the Muslim community except șulh that prohibits something that is halal or șulh that legalises something that is illegal, and the Muslims are bound by the terms (promises) they make except for the terms (promises) that prohibit the lawful or legalise the illegals."

Thus, Sulh can be regarded as a complimentary to the court system and it is under the supervision of the Syariah Judiciary Department of Malaysia (SJDM). SJDM is responsible to ensure the effectiveness and the standardisation of the administration of the Syariah Courts in Malaysia since each state has its own system of the Syariah Court (Wahed, 2015).

\section{The Necessity of having a Land Court or a Land Tribunal in Malaysia: Discussions and Analysis}

As is well known, the establishment of a tribunal for a specific jurisdiction has many advantages, among others speed and low cost. This is helpful not only to the disputing party but also to the court and society itself. Thus, when it comes to land, it also inevitably contributes to the country's financial and economic impact. So far, special tribunals and courts have been established and are recognised by the government to facilitate the litigation process. Among them are the Construction Court which was established under the Construction Industry Development Board Act 1994 (Act 520) to resolve disputes among the construction industry in the country; the Homeowners Claims Tribunal, formed under the Consumer Protection Act 1999 (Act 599), protects the interests of home buyers and recently set up is the Strata Management Tribunal under the Strata Management Act 2013 (Act 757) established for the interest of strata property owners.

Datuk Salleh Buang (2006) questioned the difficulty to set up a Land Tribunal for the people. According to him, we are aware that the number of strata property owners in our country is no more than two million, while the owners of the strata amount to twice of that. Datuk Salleh argued that the number of landowners is doubling whether or not a tribunal or a special land court is created to avoid a heated land case being tried. He also pointed out that in this case, Malaysia is lagging behind. Another ex-judge, Datuk Richard Malanjum, had reiterated several times pointing out the necessity to establish a Land Tribunal for the people of Sabah and Sarawak where cases involving Native Customary Rights (NCR) lands were on the rise then (Lai, 2016). Earlier, it was reported by Joseph (2016) that the suggestion by the ex-judge had full support by the Star Sabah Chief, Jefferey Kitingan, who mentioned that the Government of Sabah and Sarawak "...had a moral and legal duty to protect 
INTERNATIONAL JOURNAL OF ACADEMIC RESEARCH IN BUSINESS AND SOCIAL SCIENCES Vol. 10, No. 7, July, 2020, E-ISSN: 2222-6990 @ 2020 HRMARS

native land rights and ought to be more proactive to safeguard the native customary rights to land for 'land is life' for the Orang Asal...."

Chia (2014) had before that mentioned in his report of Datuk Richard Malanjum's proposal which was supported by the then Land Development Minister Tan Sri Datuk Amar Dr James Masing saying that Human Rights Commission of Malaysia (Suhakam) report titled 'National Inquiry into the Land Rights of Indigenous Peoples' (2013) had also made strong recommendations for the setting up of a special tribunal for NCR land cases.

In Queensland, Australia, a body called the Land Board has been in existence since 1884 and is aimed at resolving a variety of land-related issues, including compensation issues when land is compulsorily acquired, appeals on taxation, licensing, mortgage and mining properties.

In addition, the Land and Environmental Court located at New South Wales, Australia has been established for the past three decades. In Northern Ireland, a Land Tribunal was established in 1964 under the Lands Tribunal \& Compensation Act (North Ireland). The Tribunal is empowered to hear cases of restrictions on land, disputes between landlords and tenants, appraisal of land for tax purposes, compensation claims when land is forcibly taken and issues of rent and valuation of commercial real estate. England and Wales have also established the Environmental Court under a special law, the Tribunal Courts and Enforcement Act 2007. The special court has six chambers, of which the fifth chamber has jurisdiction over land issues and the sixth room is given jurisdiction over property and housing. New Zealand has several special tribunals, including (1) the Tenancy Tribunal, settling disputes between landlords and tenants over land titles, (2) the Real Estate Agents Tribunal, resolving licensing issues and the conduct of licensed real estate agents, and (3) the Land Valuation Tribunal, resolving cases of objections to property valuations.

In Asia, one of the countries with its own Land Tribunal is Hong Kong which created it under the Land Tribunal Ordinance (Cap. 17). The Tribunal is empowered to hear cases of building management, compulsory acquisition of property and compensation claims. The Tribunal may also hear appeals by aggrieved parties in relation to matters referred to in some of the laws of the country.

A published document available since 2012 entitled "National Land Code Review 1965 (Consultation Paper)" by the Department of Director General of Lands and Mines (JKPTG) states that the administration of land in Malaysia was very broad and complex as it involved the compliance, enforcement and implementation of several state laws, including the National Land Code, Strata Ownership Act, Town and Country Planning Act, Local Government Act, Public Enforcement Protection Act, Environmental Quality Act and so on (Buang, 2013). Taking into account this fact, referring to page 24 of the document, it is essential that a Land Court be established. This clearly shows that the establishment of a Special Land Court or a land tribunal is imperative and necessary and that Malaysia needs to take speedier steps so as not to be left behind.

Ilham (2017) also studied the justification for establishing a special tribunal to resolve disputes in connection with land today. The author based her argument on cases reported from 2005 to 2016 and related issues and argued that the existence of this tribunal is a proposition that uses the ADR method for the purpose of resolving overlaps of jurisdiction between the Civil Court and the Syariah Court.

Puan Nur'Aini Mohammed, a lawyer from Thara Singh Sidhu \& Partners, a legal firm in Johor Bahru stated (the interview took place via a telephone call on 18/8/19 at 8.20pm for a duration of 27 
INTERNATIONAL JOURNAL OF ACADEMIC RESEARCH IN BUSINESS AND SOCIAL SCIENCES Vol. 10, No. 7, July, 2020, E-ISSN: 2222-6990 @ 2020 HRMARS

minutes and 13 seconds) ${ }^{1}$ that a land tribunal is desirable and could facilitate reduce the number of land cases brought to the court since there are several unnecessary hiccups that could be avoided such as the time frame given to comply with prohibitory order which only lasts for six months. Cooperation from the land offices is an uphill task sometimes and would subsequently force the lawyers to apply to the High Court to settle caveat issues. Also, an application to the land officer for caveats although much simpler compared to the High Court application, would end up in the order not being issued because it is almost impossible to prepare all the required documents within the two months' time frame. Puan Nur'Aini further commented that in foreclosure cases, the difficulty could arise out of the procedure to fix the auction price because of the uncertainty of the current value of the property itself. Plus, there could be integrity issues when valuers from both parties (the government and private valuers) tend to team up to fix the value of the property making it unrealistic. Further, it has become very difficult nowadays to contest the foreclosure notice after rules were amended (Section 254 National Land Code (Amendment) Act 2016) favouring the banks. The author came across an article by Dr Ernest Cheong (2018), a Senior Partner in Ernest Cheong PTL Chartered Surveyors who opined that when banks in Malaysia commence with foreclosure proceedings against their borrowers, it is almost impossible for the later to succeed. This is by far related to the fact that all borrowers shall have to charge their property to the bank in order to secure a loan. Puan Nur'Aini added that the land tribunal should be presided by someone who has a legal background so that he/she could appreciate the reason the law was passed as such. She thought that it was impossible not to have a lawyer's service in land matters albeit the hearing in a tribunal because one needs a lawyer to register caveatable interest and other legal procedures to be conformed too. So, she thought that the legislator should do something about the Legal Aid Bureau that could be expanded for the benefit of the public.

On Legal Aid, another advocate interviewed was Tuan Mohd Rasheed bin Hassan, Senior Partner in Chor Pee Anwarul \& Co (conversation conducted by WhatsApp conversation on 18/08/19 at 4.28pm - 5.17pm). Tuan Rasheed was previously the chairman of the Johore Legal Aid SubCommittee. He shared his experience in handling cases that reached the Johore Legal Aid Centre. Where land cases were concerned, Tuan Rasheed mentioned that it was unrealistic for those who own a land to be eligible for legal aid. But possible land cases where the Centre could accept are tenancy cases. Then again, where tenancy cases are concerned, he stated, no point in bringing the cases to a tribunal or court unless the amount to be claimed is substantial. If tenants do not pay the rent, in normal circumstances, landlords would just ask them to leave. On the other hand, where it is the landlord who breaches the tenancy agreement, any remedy made by the tenant is just deducted from the monthly rental. On another point, Tuan Rasheed disclosed that courts are now urging for some cases to be settled by the ADR method where facts are not disputed; not much issues for witnesses to confirm and where it is more on a legal decision to be reached. On the question of whether tribunals would facilitate land cases to be settled in a speedier manner, Tuan Rasheed declared that courts nowadays have a Key Performance Index (KPI) to dispose cases within one year. With regards to land acquisitions, he said that the main issue is usually on the discrepancy of the compensation value made by both the government and private valuers.

Another lawyer approached is Puan Siti Aishah bt Abdullah from Tetuan Awi \& Co from Perak (Interview conducted via telephone call on 20/08/19 at 19/08/19 at 2.45pm for a duration of 5 
INTERNATIONAL JOURNAL OF ACADEMIC RESEARCH IN BUSINESS AND SOCIAL SCIENCES Vol. 10, No. 7, July, 2020, E-ISSN: 2222-6990 @ 2020 HRMARS

minutes and 50 seconds). The idea of having a land tribunal seems appealing for her if it involves family matters or removal of caveats. Probably because a tribunal is less formal than the court making it easier for all parties to give information in the trial. Puan Aishah also believed that simple cases such as the abovementioned removal of caveats are not time consuming compared to cases where owners of land are deceased which could cause years to be settled.

Next, Puan Aida Haniza Adnan, a Company Secretary attached to Malaysia Standard Chartered Bank Malaysia Berhad/ Standard Chartered Saadiq Berhad was interviewed to ascertain her perspective on this matter as the party involved in land matters like foreclosure and forfeiture (interview conducted via telephone call on 20/08/19 at 7.53am for a duration of 9 minutes and 1 second). From the bank's point of view, the property subject to a charge is not normally released easily although the procedure is quite straight forward. It could take months for them to be released before the bank could set for auction dates. Puan Aida mentioned that sometimes there were also problems with the Land Office whereby the officers were not that helpful or cooperative when dealing with banks. Where a tribunal is concerned, Puan Aida mentioned that anything speedy for the interest of the bank is welcomed to avoid bureaucracy and red tapes.

Puan Juhaida Jaafar, a lawyer from Wrigglesworth \& Co, was also interviewed and she is all for a Land Tribunal if it means cases can be resolved easier and at a speedier rate especially land acquisition cases (interview conducted through WhatsApp conversation on 19-20/08/19). She agreed that land cases usually take lengthy period of time to be decided. However, Puan Juhaida felt that if there is any element of fraud in the case, then it should be heard in the courts of law because it could involve examination of witnesses to establish fraud. She revealed that the Land Office has a unit that deals with distribution of intestate assets which only involves Letters of Administration under the jurisdiction of the High Court. Hence, she opined that a Land Tribunal if in existence should not touch on those matters as they are now nicely placed at the Land Office unless the assets are valued at above RM2 million.

An officer at the Alor Gajah Land Office, Puan Hajar Asmidar binti Abdul Rahim, an Assistant District Officer at the Land Development Unit was asked to give her opinion on the suggestion of a Land Tribunal and she agreed that there should be one in Malaysia (interview conducted through WhatsApp conversation on 19/8/19 at 5.46pm). Puan Hajar believed that the tribunal should be placed under a Ministry to be well monitored like the Tribunal of Consumer Claims. She was deemed to say that the person presiding the tribunal must be a judge or anyone that has a legal background and the panelists should consist of experienced land officers or those officers that have vast experience handling land matters such as pensioners from Land Office that could be appointed on a contractual basis.

A Sulh Officer from the Syariah Court in Kedah who has been handling cases using the sulh approach, Puan Wan Yusniza binti Wan Yusof, disclosed that the approach is a huge success in settling family disputes (interview conducted through WhatsApp conversation on 21/05/2020). She had shown her consensus if land disputes were to be settled using the same approach because they could be resolved in a peaceful and harmonious way. The parties do not have to go to court for trials which is one of the many advantages of a sulh settlement.

The last person interviewed by the author was the Director of the Melaka Kementerian Perdagangan Dalam Negeri, Koperasi dan Kepenggunaan (KPDNKK) himself Tuan Jaiya bin Abu who believed that where land matters are concerned, the avenue is already sufficient for the public to go to i.e. the High Court (interview conducted via telephone call on 20/08/19 at 6.03pm for a duration 
of 16 minutes and 34 seconds). Tuan Jaiya expressed his concern regarding the thought of having land matters resolved by the Tribunal of Consumer Claims (TCC) under the Ministry. He confirmed that among the major problems faced by the TCC is the delivery of notice to the party claimed is the claimant himself/herself which inevitably and easily triggers a tensed and agitated atmosphere even before the case is heard at the tribunal. When asked whether the police were approached for help for delivery of notice, Tuan Jaiya stated that even the police refused to accept the responsibility as it was not their job specification to do so and they are also having endless lists of work to be executed. In addition to that, a lot of claimants are facing difficulties because the claimed parties appear not to honour the decisions made by TCC. Hence, beating the purpose of compensation driven intention of complaining to the tribunal. Tuan Jaiya also revealed that there is now a proposal brought to the National Land Council for the inclusion of insurance in land cases that are involving fraud to protect the land owners instead of the bona fide purchasers but it is still at the early stage.

\section{Suggestions and Conclusion}

Having discovered all the above mentioned input and data, it can be concluded that a Land Tribunal/Court of any sort, does seem to be favoured to settle small claims regarding land and any interest upon it. Although the authors did not specifically mention about sulh during the interview, almost all the interviewees indirectly expressed that they would favour any dispute settlement that is harassed free and reflects humanity and kindness in the settlement. Needless to say, it may appear to be unrealistic and almost impossible to have one, steps and measures towards its existence must be initiated and gradually improved to reach the objective. The following suggestions are segregated to get a better picture of what we are suggesting.

\section{A New Scope of what can be Brought to the Tribunal of Consumer Claims (TCC)}

This requires the law to be amended. The provisions of the Consumer Protection Act 1999 must be amended to include land and any interest in land under its section 2. The definition of consumer goods should be expanded to include land and its interests because we tend to be directly linked with them on a daily basis. One of the salient features of consumer goods is that they are regularly used by the consumers daily. Although it would be difficult to redefine goods to include land, but interest in land could possibly be parked as a service under the act. For example, if a person holds a lease on a land payable monthly to the owner of the land, any dispute over that interest could probably be decided by the TCC because it probably does not involve a substantial amount. Thus, it could be proposed that only a certain limit of claim for land cases could be tried in TCC, such as below RM1 million. In addition, it was mentioned earlier by an ex-judge, land cases that need not go for trial could have been settled earlier if the case management in court were handled appropriately suggesting that a different body to tackle small claims in land matters is inevitable taking into consideration the substantial number of cases being brought to the courts of law.

The only setback for such a suggestion is probably the difficulty to accept that "land" is goods that are widely known as moveable property in the Consumer Protection Act 1999. This has long been understood as being a matter of jurisdiction for the TCC.

\section{A Specific Land Tribunal to Handle all Land Cases like the Administrative Tribunal}

It is also suggested that the provisions of the National Land Code be amended to include the establishment of a Land Court or a Land Tribunal to cater all land cases and the interests vested upon 
it. The latter is easier to come into being because of its nature that it is not as formal as the former. On this point, passing a specific act on a land tribunal to have characteristics of an administrative tribunal is also flattering as what is mentioned by M.P. Jain in his book, Administrative Law of Malaysia and Singapore (4th Edition) (2011). According to MP Jain, such a tribunal enjoys a degree of autonomy and the author states that this would seem to be the best mechanism to settle disputes outside the court system because there are elements of separation and independency from the administration. The suggested act would have all specific provisions on land disputes, the proposed settlement and the tribunal's composition which could exquisitely determine land conflicts in a speedier manner. Such an act would constantly cause uniformity in all decisions arrived at which obviously is the aspiration of any judicial system universally. Therefore, it is suggested that a specific tribunal to handle land cases could cause justice to all in all aspects

Although this is by far the best solution for a just, speedier, focused and cheaper resolution for land cases, it probably takes time for it to be established where passing a new law is in the picture. It is already anticipated that a new piece of legislation going through Parliament would probably cause foreseeable delay taking into consideration circumstances surrounding its process such as the political climate or financial status of the state and other matters.

\section{The Establishment of a Land Dispute Committee under the Housing Tribunal}

It is recommended that the sulh concept be applied in the administration of the proposed land dispute committee under the Housing Tribunal as a platform for a dispute resolution. This is so because land and housing matters are interlinked with each other. As it is, sulh is available in syariah jurisdiction for the Muslim people in syariah courts in Malaysia. By comparison, the civil courts in Malaysia do apply a similar approach in pre-trials mediation. This approach is favourable because issues regarding land are more often than not linked with family ties or close relationships between friends and neighbours. The sulh procedure is straightforward, simple and harass free. The syariah courts in each state in Malaysia has common and similar process when it comes to settling cases via sulh method. The parties only need to register their cases at the office concerned and a date is fixed for the parties to come for a discussion to settle their problem formally guided by a sulh officer who is neutral and has no connections with both parties in dispute. The focus of the discussion is for the future of the parties in dispute and that such a process not only involves mediation, it also includes principles of counseling, advising and arbitration. Therefore, if this procedure is applied in such a land dispute committee, it can save a lot of time and money without any heart breaking incidents. It is worth noted that sulh has been satisfactorily applied in family disputes in syariah courts and statistics in previous researches show that it is well accepted as a dispute resolution mechanism for such cases. Hence, it is perhaps appropriate to suggest the same amicable approach is used to settle any kinds of disputes including those related to land matters.

However, the only problem that can be envisaged from this suggestion is the lack of experienced and well trained officers to handle the procedure if any cases are brought to the committee for clearance. This could cause several difficulties such as non-uniformity in decision making or injustice for the parties concerned.

\section{Other Suggestions to Improve the Current System}

Apart from the three mentioned suggestions above, it was proposed by one of the interviewees that the role of the Legal Aid Bureau under the Ministry concerned must be revamped 
and strengthened. This is because a lot of the people who came forward to complain about their land could not afford to pay legal fees and many cases were actually genuine displays of violation of their rights. If this shortcoming could be unblocked, a lot of unsettled land cases could be disposed of. Another respondent suggested for the function of the Land Office to be improved to cater for public interest. It was mentioned in one of the interviews that officers handling land matters at the said office must be constantly equipped with the necessary up-to-date skills, both hard and soft skills. The author thinks this could necessarily solve a lot of long-standing issues pertaining to land matters brought to the office.

To conclude, it can be clearly reasoned out that an entity distinct from the functions of the ruler (the legislative, judiciary and executive) is highly desirable or perhaps obligatory to exist for the betterment of anyone who encounter problems related to land matters. Its existence is not just a sheer hospitality to help the Malaysian people but an extreme necessity to cater all land cases in this country.

\section{Acknowledgement}

Our special thanks goes to all the respondents who shared their experiences, thoughts and suggestions with us whilst conducting interviews with them over the phone and through the WhatsApp's application. It was a wonderful experience to notice that they willingly revealed what they felt about our research of whether to form a special tribunal to handle land cases in Malaysia or not. We are also indebted to the committee of International Conference on Advanced Social Research in Education, Management and Society (ICASREMS 2020) who facilitated us in the publication of this article. We would also like to declare that we did this research at our own cost and budget.

\section{Corresponding Author}

Mimi Sofiah binti Ahmad Mustafa

Law Department, Universiti Teknologi MARA Melaka Branch, Malaysia.

Email: mimi@uitm.edu.my

\section{References}

Abdul Manaf, Z. I. (2017) Resolution of Waqf Land Disputes: The Relevance of a Waqf Tribunal in Malaysia. Proceeding Paper, International Conference on Dispute Resolution, Modern Trends in Effective Disputes Resolution, Universiti Islam Antarabangsa Malaysia (UIAM) 9-10 August 2017.

Al-Ramahi, A. (2008). Sulh: A Crucial Part of Islamic Arbitration (June 30, 2008). LSE Legal Studies Working Paper No. 12/2008; Islamic Law and Law of the Muslim World Paper No. 08-45. SSRN: https://ssrn.com/abstract=1153659 or http://dx.doi.org/10.2139/ssrn.1153659

Buang, S., \& Ismail, O. (2013). The Review of National Land Code 1965 in Malaysia: Towards Sustaining Land Development in Peninsular Malaysia. 1st International Conference on Innovation and Sustainability (ICOIS), 3-4 April 2013, Sunway Resort Hotel \& Spa, Kuala Lumpur, Malaysia.

Cheong, E. (2018). "When the Bank Forecloses, How Do You Survive?". The Star. Retrieved from https://www.starproperty.my/news/9804/when-the-bank-forecloses-how-do-you-survive- 
INTERNATIONAL JOURNAL OF ACADEMIC RESEARCH IN BUSINESS AND SOCIAL SCIENCES

Vol. 10, No. 7, July, 2020, E-ISSN: 2222-6990 @ 2020 HRMARS

Chia, J. (2014). Masing: Dedicated court for NCR land cases excellent idea. Borneo Post Online. Retrieved from https://www.theborneopost.com/2014/01/23/masing-dedicated-court-forncr-land-cases-excellent-idea/

Chin, Ian. (2019). Does the Judiciary Require Reform?. Legal Network Series.

Fabri, H. R. (2019). Public and Media Access to Courtrooms: International Courts and Tribunals. In Max Planck Encyclopedia of International Procedural Law (Oxford University Press)

Fazaluddin, S. (2016). Conciliation Ethics in the Qur'an. International Journal for the Semiotics Law.

Jain, M. P. (2011). M.P. Jain's Administrative Law of Malaysia and Singapore (4th Edition). Kuala Lumpur: Lexis Nexis.

Lai, N. (2016). More support for tribunal to resolve NCR land cases. Borneo Post Online. Retrieved from https://www.theborneopost.com/2016/01/28/more-support-for-tribunal-to-resolvencr-land-cases/

Mathew, A. (2018). Analysis of Application of Principles of Justice in Arbitration. Journal of Law and Society. 22, $41-51$

Othman, A. (2001). Alternative Dispute Resolution (ADR) in Malaysia: Prospects and Challenges. Malayan Law Journal

SUHAKAM. (2013). Report of the National Inquiry into the Land Rights of Indigenous Peoples Retrieved from: http://sarawakreport.org/suhakam/suhakam-chapter1.html

Adnan, W. A., \& Buang, A. H. (2019). The Implementation of Șulh involving Real Estate Claims of Muslims in Shariah Court in Malaysia: A Survey of Previous Studies. Journal of Shariah Law Research (JSLR).

Wu, R., \& Kepli, Z. M. Y. (2011). Implementation of Land Title Registration System in Malaysia: Lessons for Hong Kong. Malayan Law Journal.

Yaacob, M. A. (1990). Undang-Undang Sivil Islam. Kuala Lumpur: Dewan Bahasa dan Pustaka.

Zainuddin, A., \& Aziz, A. (2019). Consumer Protection Act amended. The Malaysian Reserve. Retrieved from https://themalaysianreserve.com/2019/07/09/consumer-protection-actamended/

\section{Cases}

Sharip v Mitchell (1870) Leic 446

AV Asia Sdn Bhd v MEASAT Broadcast Network Systems Sdn Bhd [2014] 3 ML 61.

\section{Statutes}

Construction Industry Development Board Act 1994 (Act 520)

Courts of Judicature Act 1964

Consumer Protection Act 1999

Housing Development Act 1966

National Land Code (Amendment) Act 2016

Strata Management Act 2013 (Act 757) 